\title{
Identification of Tourism Sport Developmrnt in Panji Anom Village, Kecamatan Sukasada Buleleng
}

\author{
$1^{\text {st }}$ Syarif Hidayat \\ Prodi Pendidikan Kepelatihan Olahraga \\ FOK \\ Undiksha \\ Indonesia \\ syarif.hidayat@undiksha.ac.ic
}

\author{
$2^{\text {nd }}$ Wasti Danardani \\ Prodi Pendidikan Kepelatihan Olahraga \\ FOK \\ Undiksha \\ Indonesia
}

\author{
$3^{\text {rd }}$ Ketut Chandra Adinata Kusuma \\ Prodi Pendidikan Kepelatihan Olahraga \\ FOK \\ Undiksha \\ Indonesia
}

\begin{abstract}
Tourism sports nowadays have started to get attention from tourism business actors. Buleleng Regency as one of the regencies in Bali Province has a superiority in developing tourism businesses. one of them is by developing an alternative tourism business, namely the sports tourism sector. Buleleng Regency has natural resources, culture and a strong community structure to develop sports tourism based on local wisdom. The development of tourism sports cannot be separated from the support from all parties, one of which is universities through research. The fact is that currently there is still minimal research conducted for the development of sports tourism. This research is planned to be implemented for one year of funding. The purpose of this research in this year is that researchers try to reveal in real terms the conditions for the preparation and development of tourism sports in Panji Anom Village, Sukasada District, Buleleng Regency, Bali, focusing on research on natural conditions, local culture, and the support of village government officials in the development of tourism sports. The method used in this research is a development research method with a qualitative approach. The results of this research are the realization of a description of the potential for the development of sports tourism in the research location, namely Panji Anom Village, Sukasada Buleleng District.
\end{abstract}

Keywords-Development, Buleleng tourism, Sports Industry.

\section{INTRODUCTION}

Sports currently shows encouraging development, this is shown by the large number of people who carry out sports activities for achievement, health, and recreation. Sport is able to influence the development of modern human civilization. Sport has become a lifestyle for almost everyone and is able to influence the economy in the region, the sports business is a very potential business, so the development of sports science must continue to be carried out in order to keep up with the development of modern human needs. According to the Law of the Republic of Indonesia No. 3 of 2005 concerning the National Sports System, sports are all aspects related to sports that require regulation, education, training, coaching, development and supervision. In line with this, the sports field must continue to be developed for the advancement of the nation. Every country currently continues to explore its potential to be able to bring in tourists. Tourism functions to meet the physical, spiritual and intellectual needs of every tourist with recreation and travel and to increase state income to create people's welfare (Law of the Republic of Indonesia No. 10 of 2009, Article 3).

An interesting development is the growing number of tourists with special interests. According to Mutohir (2013) the potential for natural and cultural wealth can be developed into recreational sports and recreational tourism commodities in Indonesia, including: business tourism, beach tourism, cultural tourism, cruise tourism, nature tourism, sports tourism. The development of tourists with special interest in sports in the sense that tourists doing physical activities not only enjoy sports activities, but tourists who choose tourism activities like this are often grouped into tourists with special interests.

Panji Anom Village, Sukasada District, Buleleng Regency, is one of the villages that has a vision and mission that will develop and improve the economy by utilizing nature and culture through tourism activities. The regional potential and the potential of this village community must be optimized to improve the local economy. To realize this vision and mission, a breakthrough is needed, one of which is through research. This research is the beginning to obtain data in an effort to make Panji Anom Village a superior sports tourism in Buleleng Regency.

\section{EASE OF USE}

This research is a development research from Borg \& Gall (2001). At this stage of the research, a needs analysis was carried out by identifying the potential in the research location, with the following flow 


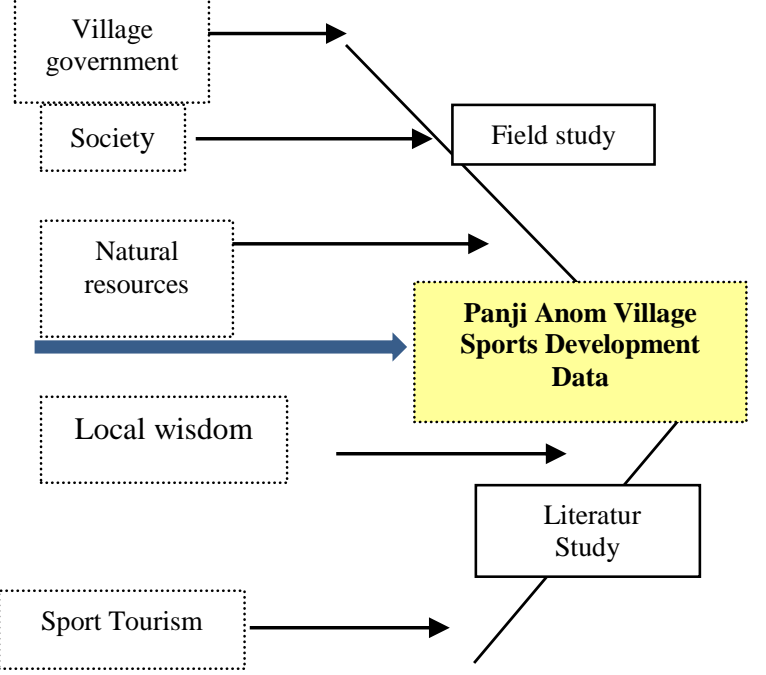

III. RESULT

\begin{tabular}{|c|c|c|}
\hline data source & Collected data & Method \\
\hline $\begin{array}{c}\text { Buleleng } \\
\text { Regency } \\
\text { Tourism } \\
\text { Office }\end{array}$ & 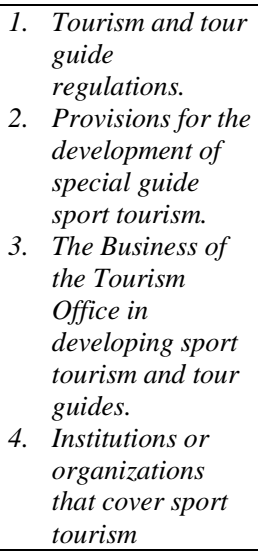 & $\begin{array}{ll}\text { 1. } & \text { Documen. } \\
\text { 2. } & \text { literturStudy }\end{array}$ \\
\hline $\begin{array}{c}\text { Village } \\
\text { Goverment }\end{array}$ & $\begin{array}{l}\text { 1. Area Map Data. } \\
\text { 2. Efforts are made } \\
\text { in developing } \\
\text { sport tourism. } \\
\text { 3. Vision, mission } \\
\text { and objectives of } \\
\text { the village. } \\
\text { 4. Village } \\
\text { Development } \\
\text { Plan } \\
\text { 5. Local Cultural } \\
\text { Potential Data } \\
\end{array}$ & $\begin{array}{ll}\text { 1. } & \text { Documen. } \\
\text { 2. Litertur study }\end{array}$ \\
\hline $\begin{array}{c}\text { Society } \\
\text {. }\end{array}$ & $\begin{array}{l}\text { 1. The superiority } \\
\text { of Buleleng local } \\
\text { wisdom. } \\
\text { 2. Challenges in } \\
\text { maintaining } \\
\text { Buleleng local } \\
\text { wisdom. } \\
\text { 3. The relationship } \\
\text { between tourism } \\
\text { and local wisdom } \\
\text { in Buleleng. } \\
\text { 4. Buleleng's } \\
\text { natural potential. } \\
\text { 5. Community } \\
\text { support in } \\
\text { developing sport }\end{array}$ & $\begin{array}{l}\text { 1. Dokumen. } \\
\text { 2. interview }\end{array}$ \\
\hline
\end{tabular}

\begin{tabular}{|c|c|c|}
\hline data source & Collected data & Method \\
\hline & tourism. & \\
\hline $\begin{array}{c}\text { natural } \\
\text { conditions }\end{array}$ & $\begin{array}{c}\text { 1.River } \\
\text { 2.Waterfall } \\
\text { 3.Mount. } \\
\text { 4.Lake. } \\
\text { 5.Jungle }\end{array}$ & $\begin{array}{l}\text { 1. Documen. } \\
\text { 2. Field study. }\end{array}$ \\
\hline
\end{tabular}

\section{DISCUSSION}

The sea area with a stretch of coast along $144 \mathrm{~km}$ and mountains that stretch from the east to the west end is geographically located at positions 8003'40 "- 8023'00" south latitude and 114025'55 "- 145027'28" east longitude, so that this has natural and cultural potential that is different from other areas in Bali Province which support the development of sport tourism based on local wisdom. It can be said that the regulations used in tourism development in Buleleng Regency are RI Law No. 5/2009, Bali Provincial Regulation No. 5/2008, Bali Province Regional Regulation No. 2/2012, Tourism Development Strategic Plan in Buleleng. It can be argued that the Buleleng Regency government through the Tourism Office has provided guidance for human resource development and has also carried out promotions both domestically and abroad. Tourism development in Buleleng Regency refers to the RENSTRA for the development of Buleleng tourism, including the development of sport tourism. It can be said that the institutions in charge of the development of sport tourism in Buleleng Regency are not yet optimal, they are still individuals or groups that are members of the company or POKDAWIS.

Data on organizations in charge of sport tourism in Buleleng are limited to water tourism, while sports that are carried out in the mountains are only in POKDARWIS in several villages in the Buleleng Regency area. Available in the village profile. This area data is displayed in the village office and on the village website Panji Anom. It has been done with the formation of Pokdrwis Puncak landep. Pokdarwis is fostered by the Buleleng Tourism Office.

Buleleng Regency is a hilly area that stretches to the south, while in the north it is lowland, in Buleleng Regency there are also volcanoes and are not volcanic. The highest mountain is Mount Tapak with a height of 1903 meters in Sukasada District while the lowest is Mount Jae with a height of 222 meters in the Gerokgak District area. Buleleng Regency also has two lakes, namely Tamblingan Lake with an area of 110 hectares in Banjar District, while Lake Buyan, which covers 360 hectares, is located in Sukasada District. The integration or relatively close proximity of the mountainous region to the coast gives its own meaning to Buleleng Regency compared to other districts in Bali Province. This unique condition makes the topography of the Buleleng Regency area often called Nyegara Gunung.

The challenge that will be encountered is the start of the younger generation to follow the foreign culture brought by tourists and the progress of today's information media. Great potential to be combined to become a special attraction. The life and culture of the local community as the main capital in developing a tourism business based on local wisdom. that so far this potential has not been optimally managed to support the implementation of trekking sports activities in the development area. 
Strongly hopes for the development of new destinations in Panji Anom Village. Rivers and waterfalls depending on the season. There are forests and hills that are attached to the name of the peak of landep. This potential includes State forests whose management is handed over to the village.

\section{CONCLUSION}

From the results of research and discussion, it can be concluded that: (a) Nature and culture in Buleleng Regency have the potential to develop sport tourism based on local wisdom, (b) The Buleleng Regency Government strongly supports these development efforts by issuing regulations in the form of regional regulations, encouraging the formation of Pokdarwis, (c) Panji Anom Village is one of the villages that has the potential to become a tourist destination, namely sport tourism, namely trekking, (d) Pokdarwis already exists but it needs assistance to manage this potential, (e) The community supports efforts to make Panji Anom village a trekking tourist destination

\section{REFERENCES}

[1] Choi,Soojin.,Leht, Xinran Y.,Morrison,AlastairM.,andJang,SooCheong (Shawn).,(2012). Structure of Travel Planning Processesand Information Use Patterns.Journal of Travel Research.51(1) 26-40. SAGE PublicationsReprints and permission:sagepub.com/journalsPermissions.nav. DOI: 10.1177/0047287510394191. http://jtr.sagepub.com.

[2] Hidayat, Syarif (2009) Guide for Sport Tourism. Prosidding Internasional Conference on Sport. UNY

[3] http://panjianom-buleleng.desa.id/index.php/first/artikel/1 diakses tanggl $17 / 2 / 2020$
[4] Loukaitou-Sideris,Anastasia.andSoureli, Konstantina. (2012) Cultural Tourism as an EconomicDevelopment Strategy for EthnicNeighborhoods Economic Development Quarterly.26(1) 50 72. Reprints and permission:sagepub.com/journalsPermissions.nav. DOI: 10.1177/0891242411422902. http://edq.sagepub.com

[5] North/South Inter Parliamentary Association. (2014). Sport tourism. Joint Ralse/L\&RS paper-1 of 2014.

[6] Pemerintah Republik Indonesia. (2005). Undang-undang no 3 tahun 2005 tentang sistem keolahragaan nasional. Jakarta: Biro Humas dan Hukun Kementerian Negara Pemuda dan Olahraga Republik Indonesia.

[7] Pemerintah Republik Indonesia. (2009). Undang-undang no 10 tahun 2009. tentang kepariwisataan Indonesia. Jakarta: Biro Humas dan Hukun Kementerian Pariwisata Republik Indonesia.

[8] Peraturan Daerah Provinsi Bali Nomor 5 Tahun 2008 tentang Pramuwisata, Lembaran Daerah Provinsi Bali Tahun 2008 Nomor 5 - Tambahan Lembaran Daerah Provinsi Bali Nomor 3.

[9] Rachel, Ryan (2012). Effects of Ecotourism and Adventure Tourism in the Santa Cruz Province, Argentina (An Undergraduate Thesis). Retrived https://dspace.carthage.edu/bitstream/handle/123456789/311.

[10] Rajmund, Tomik. (2013). Active sport tourism a survey of student of tourism and recreation. Journal of Tourism, Recreation \& Sport Management, 1(2013), 13-17

[11] Ridwan, Mohammad. (2012). Perencanaan dan pengembangan pariwisata. Medan: Sofmedia.

[12] Rodrigues,Aurea.,Kastenholz, Elisabeth.,dan Rodrigues, Apoló nia.(2010). Hiking As A Wellness Activity An Exploratory Study OfHiking Tourists In Portugal. Journal of Vacation Marketing16(4) 331-343.Reprints permission:sagepub.co.uk/journalsPermissions.nav.DOI: 0.1177/1356766710380886.jvm.sagepub.com

[13] Suyitno, Bambang. (2013). Kebijakan pembangunan destinasi pariwisata. Yogyakarta: Gava Media

[14] Singsomboon, Termsak. (2013). Tourism promotion and the use of lokal wisdom through creative tourism process. International

[15] Journal of Business Tourism and Applied Science, 2(2), 32-37 